\title{
The Critical Thinking Skills Analysis of High School on Rotational Dynamics
}

\author{
Yurike Margaret Takus ${ }^{1}$, Widha Sunarno ${ }^{2}$, Daru Wahyuningsih ${ }^{3}$ \\ Mahasiswa Program Studi Pendidikan Fisika, Program Pascasarjana, Universitas Sebelas \\ Maret, Surakarta, $57126^{1,2,3}$ \\ \{ margaretyurike@gmail.com¹, widhasunarno@gmail.com ${ }^{2}$, daruwahyuningsih@gmail.com ${ }^{3}$ \}
}

\begin{abstract}
. 21st-century learning emphasizes the importance of collaboration, creativity, critical thinking, and communication. Critical thinking skills is one thing that students need to have in order to solve problems. Based on the results of a survey by Trends in International Mathematics and Science Study (TIMSS), students in Indonesia rank 46 out of 51 countries in the field of science. This study aims to analyse the critical thinking skills of students of grade XI in SMA Negeri 5 Surakarta on rotational dynamics materials. The method used in this research is descriptive quantitative. Data were collected by giving a multiplechoice test that based on five critical thinking skills indicators by ennis. Tests were given to 70 students. The test result shows critical thinking skills of $51.4 \%$ students are low, $34.3 \%$ are moderate, and $14.3 \%$ are high categorized. Critical thinking skills per indicator, for elementary clarification $61 \%$ is high, the basis for the decision $51.9 \%$ is moderate, inference $46.7 \%$ is moderate, advanced clarication $21.4 \%$ is low and strategies and tactics $25.2 \%$ is low. The average critical thinking skills of all the students of grade XI in SMA Negeri 5 Surakarta on rotational dynamics is $45 \%$, it can be classified in moderate categorized.
\end{abstract}

Keywords: Critical Thinking Skills; Rotational Dynamics

\section{Introduction}

Education in the 21 st century emphasizes student success, not only on academic skills but also on success in life [1]. Therefore, learning in the 21 st century must support the achievement of these educational goals. This learning emphasizes the importance of $4 \mathrm{C}$ achievements, namely collaboration, creativity, critical thinking, and communication [2]. Learning in science is also directed towards 21 st century learning. Based on the results of a survey conducted by Trends in International Mathematics and Science Study, students in Indonesia are ranked 46th out of 51 countries in the field of science [3].

Physics as a branch of science is one of the subjects in schools which in learning is expected to lead to 21 st century learning. Physics learning related to natural phenomena has the goal of making students think critically, logically and creatively and solve related problems with the phenomenon. Therefore, interaction between teachers, peers, and the environment is needed to solve existing problems. One of the abilities needed to solve problems is critical thinking. 
Critical thinking is a reflective thinking that focuses on determining what should be believed or done [4]. In addition, critical thinking which is part of high order thinking skills (HOTS) must be based on efforts to collect the necessary information, look for reasons, and also need to consider other people's opinions before doing something [5]. The skills to think critically is one of the important factors in learning physics, because it can help students draw a conclusion about something by considering the facts and data. The indicators of critical thinking skills according to Ennis are formulated in the table below.

Table 1. Critical Thinking Skills [6]

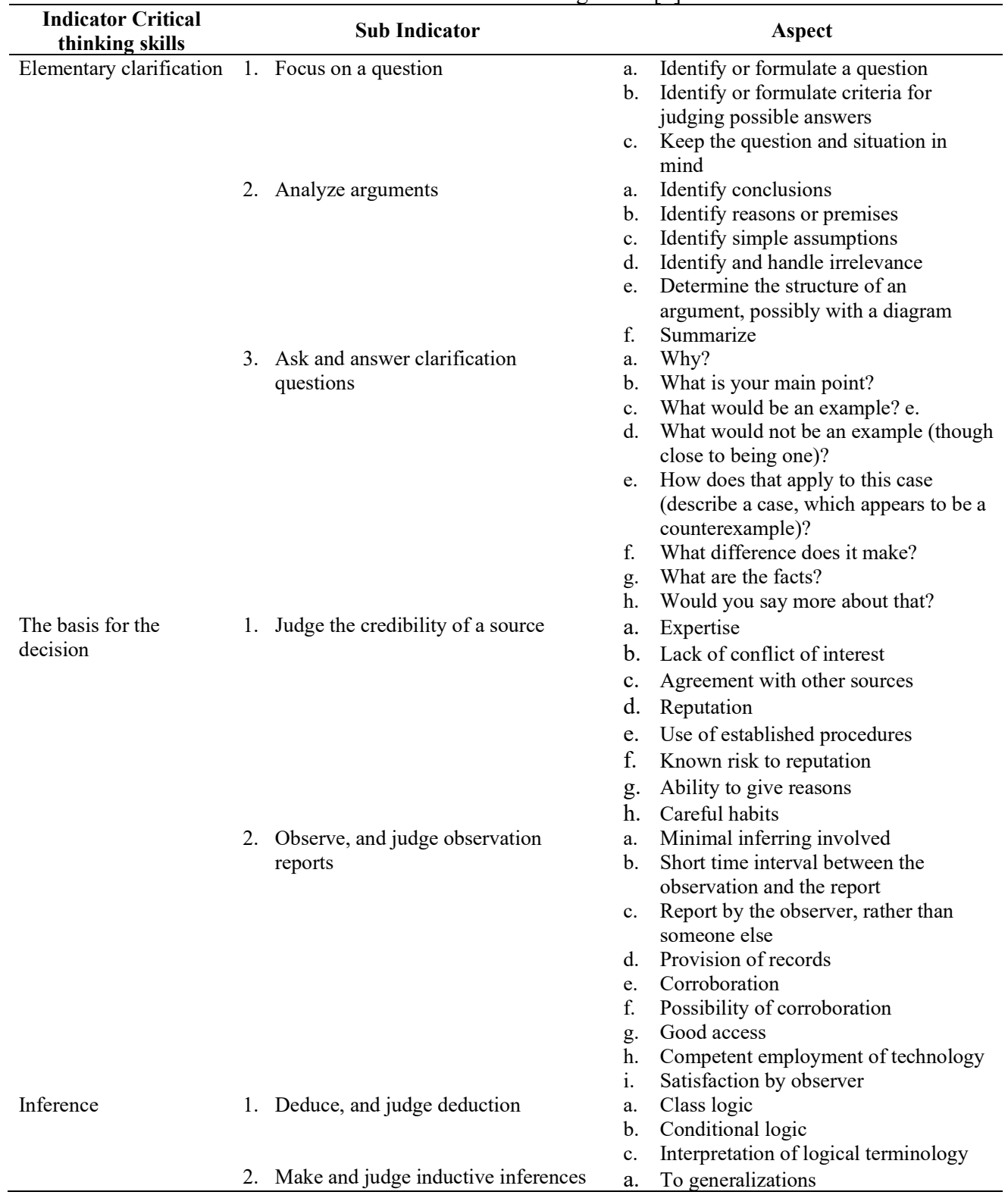




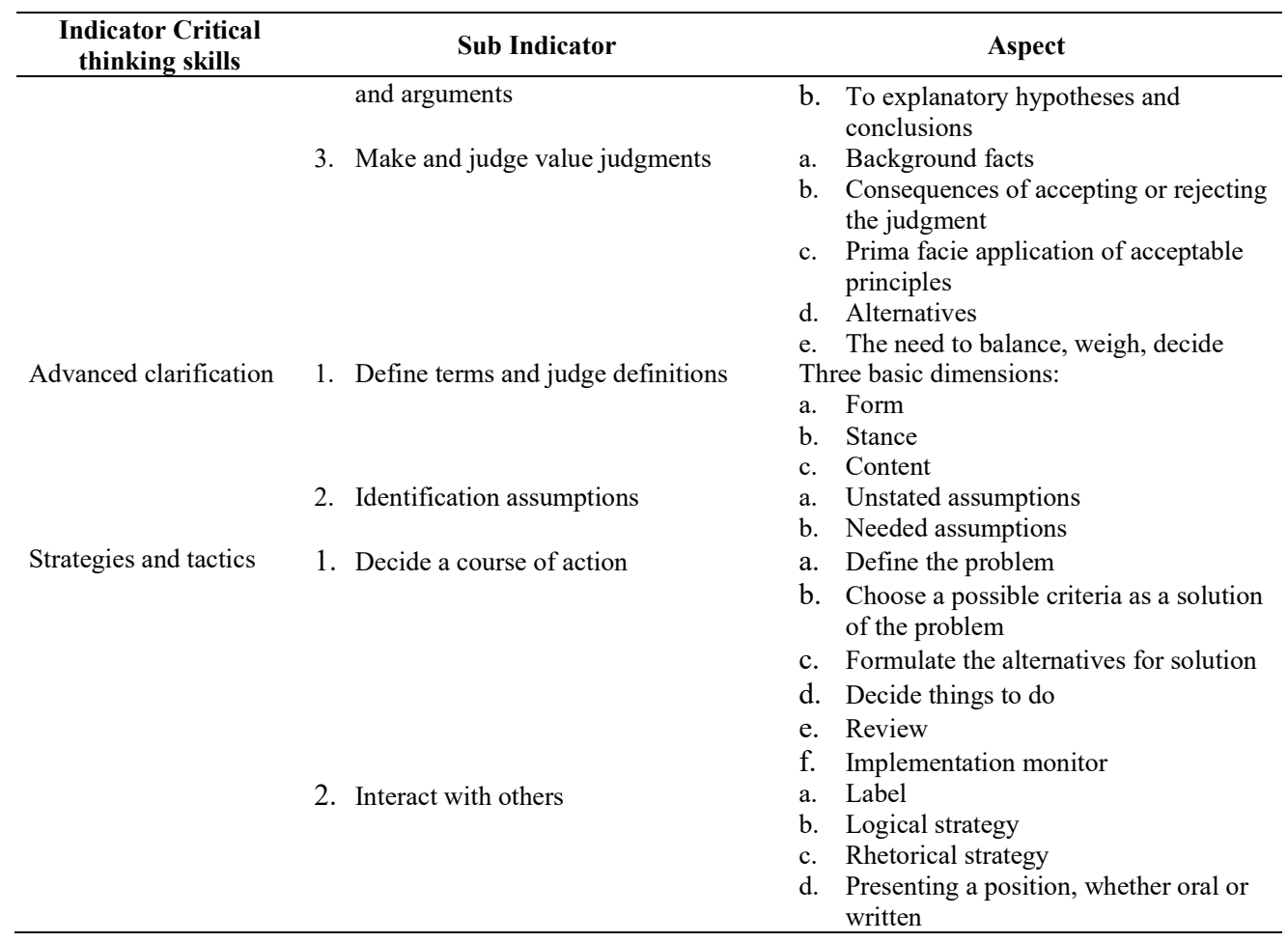

This indicator helps to see the extent to which students in the learning process use critical thinking. Critical thinking that is accustomed to educators to students provides opportunities for students to understand and take an active role in learning. The skills to think critically provides benefits for students, namely students are more effective in learning, ask more challenging questions, and are more intensely involved in learning [7]. Based on this background, the problem raised was how students critical thinking skills were based on five indicators according to Ennis. The purpose of this study was to analyze the critical thinking skills of class XI students in the rotation dynamics material.

\section{Methodology}

The method used in this research is descriptive quantitative. The sample in the study was 70 students of class XI SMA Negeri 5 Surakarta. The data were obtained by giving a test of 15 multiple choice questions on the rotation dynamics material. The questions are arranged based on 5 indicators of critical thinking skills, namely elementary clarification, the basis for the decision, inference, advanced clarication, and strategies and tactics. Data analysis was performed after the data was collected using descriptive analysis techniques in the form of a percentage which was calculated using the following formula [8].

$$
\mathrm{NP}=\frac{\mathrm{R}}{\mathrm{SM}} \mathrm{X} 100 \%
$$


Keterangan:

$\mathrm{NP}=$ percent value

$\mathrm{R}=$ obtained score

$\mathrm{SM}=$ maximum score

The research data were grouped into five categories, namely very low, low, moderate, high, and very high with the following grouping categories:

Table 2. Critical Thinking Skills Category [9]

\begin{tabular}{lc}
\hline Categories & Score (\%) \\
\hline Very high & $81-100$ \\
High & $61-80$ \\
Moderate & $41-60$ \\
Low & $21-40$ \\
Very low & $0-20$ \\
\hline
\end{tabular}

\section{Results and Discussion}

The following are the results of research data analysis and discussion:

Table 3. Critical thinking skills students as a whole

\begin{tabular}{lc} 
Categories & Student percentage (\%) \\
Very high & 0 \\
High & 14.3 \\
Moderate & 34.3 \\
Low & 51.4 \\
Very low & 0 \\
\hline
\end{tabular}

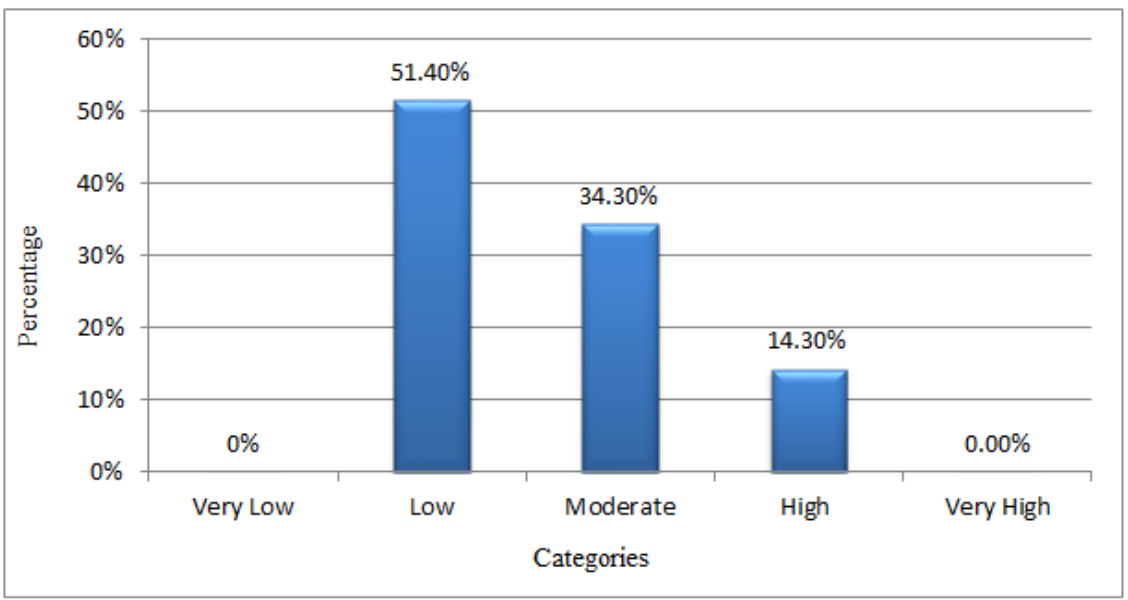

Fig. 1. Result of critical thinking skills students as a whole

Table 3 shows the students overall critical thinking skills. The highest percentage of students critical thinking skills was in the low category at $51.4 \%$ of the total students. Based on these results, it can be seen that half of the students are still in the low category and only $14.3 \%$ of students are in the high category. This shows that students critical thinking skills, 
especially in the matter of rotational dynamics, really need to be improved. The learning process that makes students active can be one way to develop students critical thinking skills. In line with what Murawski said, that students critical thinking skills are more effective in the learning process where students can ask challenging questions, which means the student is able to analyze every problem [7].

Table 4. Critical thinking skils per indicator

\begin{tabular}{lccc}
\hline \multicolumn{1}{c}{ Indicator } & Percentage (\%) & Categories & Average (\%) \\
\hline Elementary clarification & 61 & Tinggi & \\
The basis for the decision & 51.9 & Sedang & \\
Inference & 46.7 & Sedang & 45 \\
Advanced clarification & 21.4 & Rendah & (Sedang) \\
Strategies and tactics & 25.2 & Rendah & \\
\hline
\end{tabular}

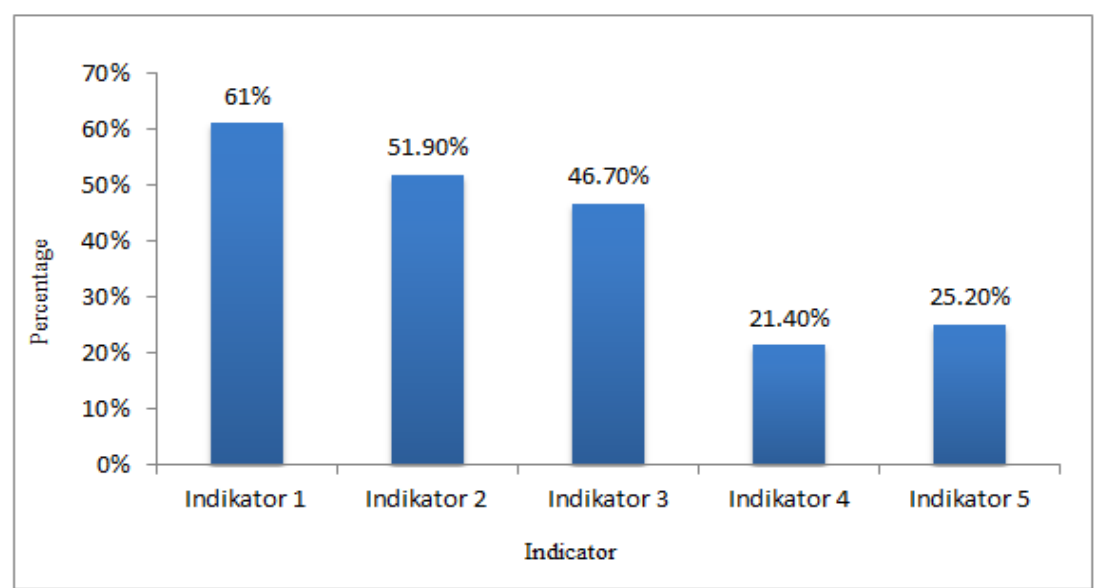

Fig. 2. Result of critical thinking skills students per indicator

Table 4 shows the students' critical thinking skills on each indicator according to Ennis. Based on the results above, it can be seen that the indicator of critical thinking skills with the highest percentage of achievement is elementary clarification, which is $61 \%$ and is categorized as high. While the lowest is the advanced clarification indicator at $21.4 \%$ which is included in the low category. Therefore, it appears that students have no difficulty solving problems that are included in the elementary clarification indicators. However, in advanced clarification, students experienced difficulties. This can be seen in the indicators of advanced clarification, the indicators of strategy and tactics are included in the low category, namely $25.2 \%$. This exhibits that students still lack critical thinking skills when solving problems in this category. Two other indicators, namely the basis for the decision and inference are in the moderate category. This difference in achievement indicates that the questions or advanced problems still cannot be resolved properly by students. At an advanced level, solving problems requires higher critical thinking skills. This can be seen in the table of critical thinking skills, where the aspects of the indicators of advanced clarification and strategy and tactics are more difficult than other indicators [6].

Based on the results of this analysis, it can be seen that the students critical thinking skills in the rotation dynamics material are still categorized as low when viewed on each indicator. 
Overall, the average critical thinking skills of students is $45 \%$ and can be classified in the moderate category. Therefore, in the learning process, methods that can improve students critical thinking skills should be used. This method can be in the form of problem based learning, discovery learning, or other methods that support active students in learning. As supposed by Majid and Rohman, learning such as a problem based learning model can develop thinking skills, problem solving, and help students become independent. This model challenges students to "learn how to learn" and work to find solutions to problem solving [10].

\section{Conclusion}

Based on data analyse, average critical thinking skills student of grade XI in SMA Negeri 5 Surakarta on rotational dynamics materials is $45 \%$, it can be classified in moderate categorized. Results also shows critical thinking skills of student per indicator can be classified in high, moderate, and low categorized. Based on this research, critical thinking skills of student still needs to be improved. Critical thinking skills can be improved by applying learning models that can make students more active during the learning process in class. Students active role in the learning process can stimulate challenging questions that require students to think critically to solve problems.

\section{Acknowledgments}

The researchers express appreciation to all those who have helped in doing this research, especially to students and teacher partaking in the data collection process.

\section{References}

[1] Chalkiadaki,A.: A Systematic Literature Review of 21st Century Skills and Competencies in Primary Education. International Journal of Instruction. pp. 1-16 (2018)

[2] Selman, Y. F.: Evaluation of The Implementation of 4C Skills in Indonesian Subject at Senior High Schools. Indonesian of Educational Journal. pp. 244-257 (2020)

[3] Nurvicalesti, N.: Kemampuan Literasi Matematika pada Pembelajaran Survey, Question, Read, Reflect, Recite, Review (SQ4R), berpendekatan Realistik. Vol.2, pp. 103-108. PRISMA, Semarang (2019)

[4] Ennis, R. H. (1987). A Taxonomy of Critical Thinking Dispositions and Abilities. New York: W.H Freeman.

[5] Sani, R. A. (2019). Soal Fisika HOTS. Jakarta: Bumi Aksara.

[6] Ennis, R. H. (1996). Critical Thinking. New Jersey: Prentice-Hall Inc.

[7] Murawski, L. M.: Critical Thinking in the Classroom....and Beyond. Journal of Learning in Higher Education. pp. 25-30 (2014)

[8] Ngalim, P. (2013) Prinsip-Prinsip dan Taknik Evaluasi Pengajaran. Bandung: Remaja Rosdakarya.

[9] Arikunto, S. (2003). Prosedur Penelitian, Suatu Praktek. Jakarta: Bina Aksara.

[10] Majid, A., \& Rochman, C. (2015). Pendekatan Ilmiah dalam Implementasi Kurikulum 2013. Bandung: PT. Remaja Rosdakarya. 